\title{
Modified Bingo Chromosome Game: An Innovative Approach in Teaching Biology
}

\author{
Marisol Solis-Foronda \\ Faculty of Science, College of Education, Isabela State University, Philippines
}

Received August 28, 2020; Revised September 29, 2020; Accepted November 1, 2020

\section{Cite This Paper in the following Citation Styles}

(a): [1] Marisol Solis-Foronda , "Modified Bingo Chromosome Game: An Innovative Approach in Teaching Biology," Universal Journal of Educational Research, Vol. 8, No. 11B, pp. 5986 - 5990, 2020. DOI: 10.13189/ujer.2020.082234.

(b): Marisol Solis-Foronda (2020). Modified Bingo Chromosome Game: An Innovative Approach in Teaching Biology. Universal Journal of Educational Research, 8(11B), 5986 - 5990. DOI: 10.13189/ujer.2020.082234.

Copyright $\bigcirc 2020$ by authors, all rights reserved. Authors agree that this article remains permanently open access under the terms of the Creative Commons Attribution License 4.0 International License

\begin{abstract}
Recently there has been increasing interest in the use of instructional games because of their applied; and dynamic nature can heighten the learner's motivation and interest more effectively than classroom lectures. This study utilized the descriptive-quantitative research design particularly the one-group pretest-posttest design to determine the acceptability and effectiveness of Modified Bingo Chromosome game in teaching the topic Chromosomal Identification. Modified Bingo chromosome is a teaching tool designed to fully understand the seven groups of chromosomes in a form of a game. It aimed to teach students in arranging and matching the correct pair of chromosomes through an interactive game. The participants were purposely selected considering that they should be enrolled in a science subject with a topic Chromosome Banding in the syllabus. Thirteen Ph. D. in Science Education students were taught the topic Chromosomal Identification using the teaching tool developed during the first validation and twenty Bachelor of Secondary Education students for the second validation. The pre-test and post-test results were subjected to t-test of independent means to determine whether the treatment was effective or not. The $\mathrm{t}$-values $(\mathrm{t}=-2.25 ; \mathrm{p}<0.05$ and $\mathrm{t}=-5.97$; $\mathrm{p}<0.05$ ) showed that there was a significant difference in the pre-test and post-test of the students. It can be concluded therefore that Modified Bingo Chromosome is an effective tool for teaching Chromosomal Identification. Hence, it is recommended that this additional tool be implemented for teaching the topic to students.
\end{abstract}

Keywords Ph.D. Science Ed, Teaching Tool, Chromosomal Identification, Interactive Game, Education Students

\section{Introduction}

One of the important topics taught in Biology subject in science classroom is the visualization of human chromosome in somatic cells. This topic cannot be easily grasped by most of the students when taught by discussion method only because of its abstract nature. Chromosomal identification, though important, seems to be taken for granted by the students because of its complexity. The students find it difficult to understand and too abstract to visualize or imagine an observation that oftentimes repel them from learning the topic. A concrete example or a representation of the actual process through pictures can help the students understand the topic in an easy manner. The teacher may also use a microscope if available in the science classroom to teach the metaphase or anaphase part of the cell cycle to view the three key features used to identify chromosomes. The learning process in the classroom should be flexible to the needs of the students. As it has been argued, young people have changed in ways that turn them off to conventional instruction [1]. The paradigm shift in education brought by scientific discoveries and revolutionary technologies in the $21^{\text {st }}$ century has changed the way the students learn [2][3]. The change in the perspective and preference of the students in learning poses a big challenge to the part of the teachers. The teachers in the science classroom must find ways and means on how to communicate scientific information in a manner that arouses the interest and learning of the 
students.

Recently there has been increasing interest in the use of games in teaching. Game-based learning is a strategy that uses a certain game in teaching with defined learning outcomes [4]. Game-based learning provides experiences that the players enjoy and want, thus motivating and engaging them to continue [5][6][7]. Also, it has been suggested that instructional games like, the Modified Bingo Chromosome Game, because of their applied and dynamic nature, can heighten the learner's motivation and interest more effectively than classroom lectures [8]. Another suggested benefit of instructional games is that they may improve the retention of learned skills and knowledge [9]. However, there should be a balance between the desire for game play and the need to cover the subject matter [10]. Game-based learning should consider the integrated viewpoints of cognitive, motivational, affective, and sociocultural perspectives [11].

In the Philippines, the dismal results of the Trends in International Science and Mathematics Study and the National Achievement Test reflect the students' difficulty with school science. Moreover, it has been observed in the classroom that students particularly science students consistently display difficulty in understanding abstract topics in science such as chromosome banding and cell division. Considering the importance of game-based in the learning of the students, the modified bingo chromosome game is considered in the teaching of chromosome banding.

Modified Bingo Chromosome Game is a teaching tool designed to fully understand the seven groups of chromosomes in a form of a game. One of the strengths of this tool is highly visual nature and represents the key information in compelling the visual form of human chromosomes. It aimed to teach students arrange and match the correct pair of chromosomes through an interactive game. In this context, this study would like to impart the above information in a way that it would not appear abstract to them through a game of skill. Also, it aimed to find out if Bingo chromosome is an effective tool for the students to better understand chromosomal identification.

\section{Methods}

\subsection{Research Design}

To determine the validity and effectiveness of the modified bingo chromosome game as a tool in teaching the topic chromosomal identification, a combination of descriptive-quantitative research is designed. The descriptive design was used to describe the responses of the participants as to the usability of the tool. However, the quantitative design employing the one group pretest-posttest design was utilized to determine the learning effectiveness of the game in teaching Chromosomal Identification to the selected participants.

\subsection{Study Group}

The study groups were purposely selected considering the criteria: 1) students or the participants were officially enrolled with the subject containing the topic Chromosome Banding in the syllabus; 2) students or the participants were taking science education as the specialization. The first validation of the Modified Bingo Chromosome was done using the thirteen students who were enrolled in the subject Cytogenetics taking up Ph.D. Science Education at Philippine Normal University, Manila. The second validation of the teaching tool was done to the twenty students who were enrolled in the subject Genetics taking up Bachelor of Secondary Education Major in Physical Science at Isabela State University, Cauayan participated in the research study. The students were informed of the purpose of the study and the result of the test would not in any way affect their grades in the subject.

\subsection{Research Tool}

The Modified Bingo Chromosome Tool is a game-based approach in teaching the topic chromosomal identification, which is based on the popular game Bingo, also called Lotto. Instead of using a card, a magnetic board divided into six columns and four rows to make twenty-four boxes is used. Each box has a number from one to twenty-four corresponding to the 24 pairs of chromosomes. An image of an unpaired human chromosome is positioned in each matching number in the box while the corresponding chromosome pair of the 24 images of human chromosomes is placed in a separate bowl. And like the lottery game, student has to draw a chromosome image from the bowl and find its correct partner in the magnetic board by positioning it beside the unpaired chromosome. The students can determine the correct pair of the human chromosomes by carefully examining the three key features such as: 1) size, 2) banding pattern and 3) centromere position are essential. The human chromosomes are arranged into seven groups based on size and centromere location. The centromeres can be found in the middle of the chromosome (median), near one end (acrocentric), or in between these first two (submedian). By examining these key features in the modified bingo chromosome tool, the students are taught how to identify the 23 pairs of human chromosomes. 


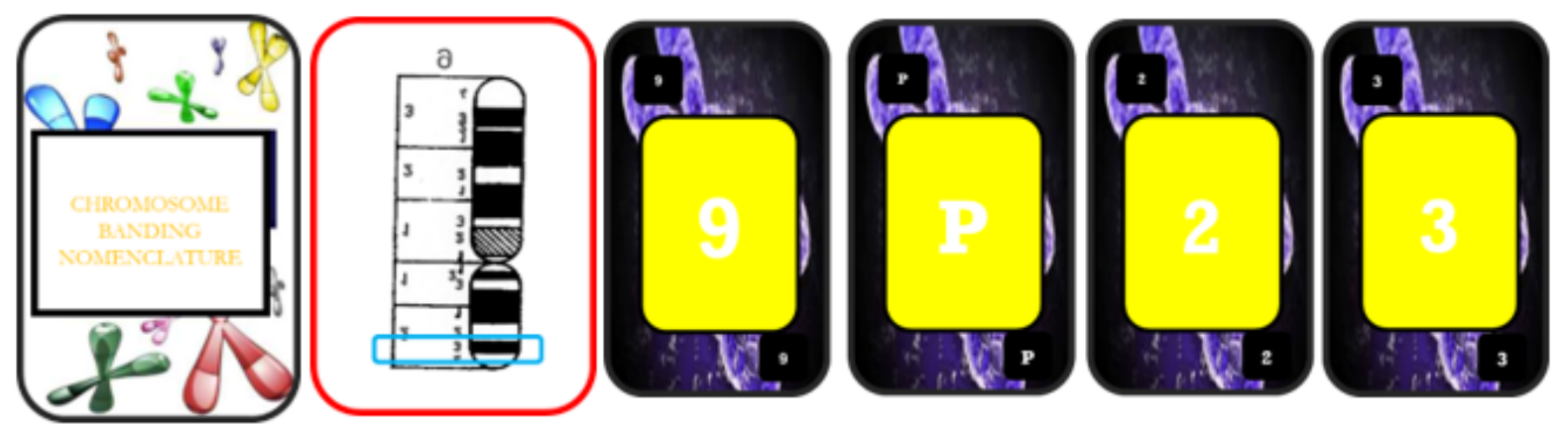

Figure 1. Sample Cards of the Modified Bingo Cards (Adapted from Tamayo, 2018).

\subsection{Data Collection}

A single group (one class) was purposively selected to validate the effectiveness of the tool. Prior to the utilization of the game in teaching the topic Chromosomal Identification, a 15-item pre-test was administered to serve as a baseline data. After the pre-test, a short discussion of different groups of chromosomes was done; right after the short discussion the Bingo chromosome game was introduced. The students in the first validation were divided into 3 groups and the students in the second validation were divided into 4 groups and each group was given the tool. Numbers were drawn by the teacher, one at a time, from the bowl and the number drawn represented the corresponding unpaired chromosome in the magnetic board.

The students had to look for its pair in the separate box and had to post it beside the unpaired chromosome on the magnetic board. The same process was repeated until all the chromosomes had pairs. The group which had the highest number of correct pairs of chromosomes was declared as the winner. After the bingo chromosome game, a 15-item post-test was administered to determine if there was a difference in the result of the pre-test. Aside from the pre-test and post-test, the students also evaluated the teaching tool based on the following criteria: ease of use, accuracy of tool, appeal of the tool to user, easy to create/develop, and cost of production. Written suggestions on how to improve the teaching tool were also generated from the students.

\subsection{Data Analysis}

The data collected in this study were analyzed using the software SPSS. A simple frequency count was used on the descriptive part and the results of the pre-test and post-test were subject to parametric t-test for correlated samples to determine if there was a significant relationship between the Modified Bingo Chromosome Game and the achievement in the topic chromosome identification. The effectiveness of the game was limited only to the topic chromosome identification and to the selected participants of this study.

\section{Results}

Figure 1 presents the perceptions of the participants in using the Modified Bingo Chromosome Game. The game was evaluated using the criteria such as: ease of use, accuracy of tool, appeal of the tool to user, easy to create or develop, and low cost of production. As to the first criterion, twenty-seven (27) of the participants agree that the game is easy to use while only six (6) participants disagree. Moreover; almost all of the participants agree that the game is an accurate tool in teaching chromosome identification. Similarly, twenty-four (24) participants agree that the game is appealing to them and twenty-six (26) agree that it is easy to create or develop. Finally, eighteen (18) participants agree that the game is low cost while fifteen (15) disagree. In addition, the students also wrote their own suggestions on how to improve the teaching tool. According to the students, the tool can be used in giving examination and since the tool was designed as a teaching tool; it should be made visible enough especially in a large class, therefore it should be made bigger and colorful. In general, they evaluated the Bingo Chromosome as an amazing teaching tool. These results only show that the modified bingo chromosome game has captured the viewpoints necessary for game-based learning.

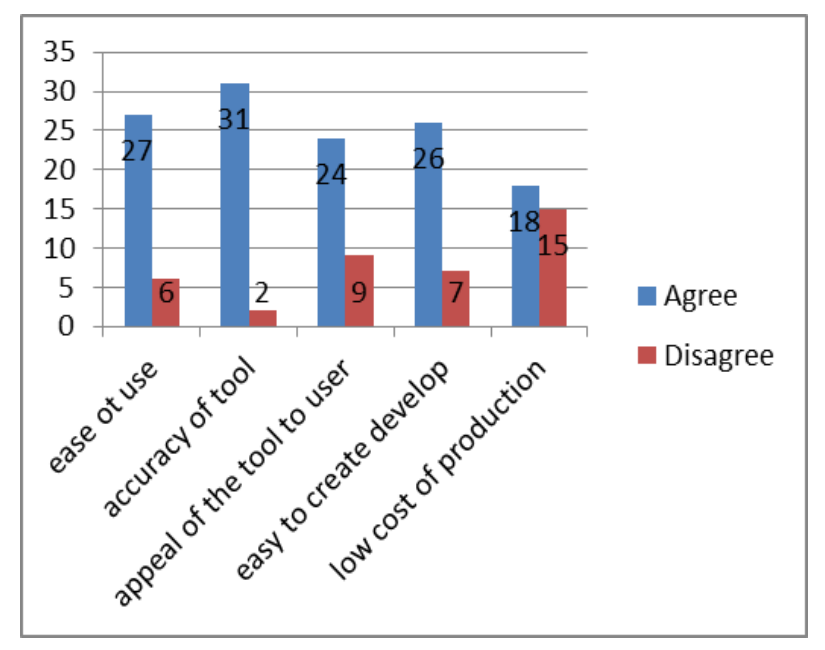

Figure 2. Responses of students $(\mathrm{n}=33$ ) to the survey on their perception of the Modified Bingo Chromosome Game. 
Table 1. T-value Results Between the Pretest and Posttest

\begin{tabular}{|c|c|c|c|c|c|c|c|c|}
\hline \multirow{2}{*}{ Variables } & \multicolumn{2}{|c|}{ Means } & \multicolumn{2}{|c|}{ SD } & \multicolumn{2}{|c|}{ T-value } & \multicolumn{2}{|c|}{ p-value } \\
\hline & Ph.D. & BSE & Ph.D. & BSE & Ph.D. & BSE & Ph.D. & BSE \\
\hline $\begin{array}{l}\text { Pre } \\
\text { test }\end{array}$ & 3.69 & 1.95 & 1.32 & 1.60 & \multirow{2}{*}{$-2.25^{*}$} & \multirow{2}{*}{$-5.97^{*}$} & \multirow{2}{*}{0.00011} & \multirow{2}{*}{$9.59 \mathrm{E}-06$} \\
\hline $\begin{array}{c}\text { Post } \\
\text { test }\end{array}$ & 7.93 & 2.50 & 2.50 & 2.14 & & & & \\
\hline
\end{tabular}

*significant

The results in Table 1 present the mean scores and t-values of the pre-test and post-test of the students. It shows that the pre-test mean-score $(x=3.69 ; \mathrm{SD}=1.32)$ of the Ph.D. students has increased in the post-test mean-score $(x=7.93 ; \mathrm{SD}=2.50)$. Similarly, the pre-test mean-score of $1.95(\mathrm{SD}=1.60)$ of the BSE students has increased to 2.50 $(\mathrm{SD}=2.15)$ in the post-test. The pre-test and post-test mean scores of the students were subjected to inferential statistics particularly the T-test for correlated samples to determine if there is a significant difference in the mean scores of the students. The difference in the mean scores can be used to assess the effectiveness of the Modified Bingo Chromosome in teaching the topic 'Chromosomal Identification'. The $\mathrm{t}$-values $(\mathrm{t}=-2.25 ; \mathrm{p}<0.05$ and $\mathrm{t}=-5.97$; $\mathrm{p}<0.05$ ) show that there is a significant difference in the pre-test and post-test of the students in both groups. It means that the difference in the pre-test and post-test of the students is not negligible. Thus, the increase in the mean scores is considerably important in determining the achievement of the students in the topic Chromosomal Identification.

\section{Discussion}

The perception of the students in the areas of ease, accuracy, appeal, and cost of the game showed the positive evaluation and acceptance in using it in teaching the topic Chromosomal Identification. The positive evaluation of the students can be attributed to the nature and characteristics of the game, which is adapted from a popular lottery game. Moreover, the game-based learning tool used in this study adheres to the general viewpoints of game-based learning. Using game-based learning like the modified bingo chromosome in teaching provides experiences that the players enjoy and want thus motivating and engaging them to continue [5][6][7]. Moreover, there are consistent results that show that games generate interest and motivation in learners and appear to be as effective as other techniques for teaching factual information, principles, and concepts [12][13]. As observed in this study, the results in the study groups are consistently signifying that both groups have the same perceptions of the positive impact of the game in learning chromosomal identification. Furthermore, the significant difference in the mean scores of the pre-test and post of the students implies an improvement in the learning or achievement of the students in the topic. Many experts in the field of Psychology have long established the important role of play in learning. Modified Bingo Chromosome Game which is a form of play can be an integral component of students' stages of cognitive development. This assumption is also supported by the theory of Piaget [14]. Another important feature of the game is that it involves player engagement most specially that the game is designed to be played in groups. The players or members engagement involves their cognitive engagement (mental processing and metacognition), affective engagement (emotion processing and regulation), and behavioral engagement (gestures, embodied actions, and movement) [15]. The group members work together to complete a task and in the process of working their cognitive, affective, and behavioral skills are enhanced. In connection, the increase in the achievement of the students as measured by the mean test scores in the pre-test and post-test can be attributed to the students' goal to learn new things and learning new skills [16] which can be seen as a characteristic of the game. However, it should be emphasized that games are just used to enhance the students' skills, and it is the teacher's judgement to discern the appropriate application of the game in the classroom [17].

\section{Conclusions}

Based on the findings of the study, the Modified Bingo Chromosome Game can be used in teaching Chromosomal Identification to help the students understand the topic in an easy manner. The reason is that games appear to be as effective as other techniques for teaching factual information, principles, and concepts like chromosome identification. Though the game proved to be an effective tool to enhance the students' achievement particularly in learning chromosomal identification, an in-depth study considering a longer time and more participants is recommended to further establish the validity and reliability of the tool.

\section{REFERENCES}

[1] Prensky, M, "Digital game-based learning (on-line version)” in New York: McGraw-Hill, 2001

[2] International Council for Science (ICSU), "Report of the 
ICSU Ad-hoc Review Panel on Science Education”, International Council for Science, Paris, 2011

[3] NAS (National Academy of Sciences), "Rising Above the Gathering Storm, Revisited: Rapidly Approaching Category 5”, National Academies Press, Washington, D.C., 2010

[4] Shaffer, D., Halverson, R., Squire, K., Gee, J., "Videogames and the future of learning", Madison: University of Wisconsin-Madison, Wisconsin Center for Education Research (NJ1), pp. 2005-4, 2005

[5] Gee, J., "What video games have to teach us about learning and literacy”, in New York, NY: Palgrave Macmillan, 2003

[6] Zusho, A., Anthony, J., Hashimoto, N., Robertson, G., “Do video games provide motivation to learn?” in F. C. Blumberg (Ed.), Learning by playing: Video gaming in education, Oxford, UK: Oxford University Press, 2014, pp. 69-86

[7] Ryan, R., Rigby, C., Przybylski, A., "The motivational pull of video games: A self-determination theory approach", Motivation and Emotion, vol. 30, pp. 344-360, 2006, http://dx.doi.org/10.1007/s11031-006-9051-8.

[8] Greenblat, C., "Teaching with simulation games: A review of claims and evidence”, in C. S. Greenblat \& R. D. Duke (Eds.), Principles and practices of gaming-simulation, Beverly Hills, CA: Sage Publications, 1981, pp. 139-153

[9] Pierfy, D., "Comparative simulation game research: Stumbling blocks and stepping stones", Simulation and Games, vol. 8, no. 2, pp. 255-268, 1977

[10] Plass, J., Perlin, K., Nordlinger, J., “The games for learning institute: Research on design patterns for effective educational games", Paper presented at the Game Developers Conference, San Francisco, CA, 2010

[11] Plass, J., Homer, B., Kinzer, C., "Foundations of game-based learning”, Educational Psychologist, vol. 50, no. 4, pp. 258-283, 2015

[12] Dorn, D., "Simulation games: One more tool on the pedagogical shelf” Teaching Sociology, vol. 17, no. 1, pp. $1-18,1989$

[13] Tamayo, P. A., Development and Effectiveness of a Modified Educational Card Game as Supplementary Material for a Game-Based Science Learning Strategy in Understanding Chromosome Banding Nomenclature. Advanced Science Letters, 24(11), 8243-8247, 2018

[14] Piaget, J., "Play, dreams and imitation in childhood”, in New York, NY: W. W. Norton, 1962

[15] Domagk, S., Schwartz, R., Plass, J., "Interactivity in multimedia learning: An integrated model”, Computers in Human Behavior, vol. 26, pp. 1024-1033, 2010, http://dx.doi.org/10.1016/j.chb.2010.03.003.

[16] Elliot, A., "A conceptual history of the achievement goal construct”, in A. J. Elliot, \& C. S. Dweck (Eds.), Handbook of competence and motivation, New York, NY: Guilford Press, 2005, pp. 52-72

[17] Ida Z., Ervina C., Simatupang, H., Investigating a PC-based Student-made Application and Its Implementation in Young Learners' Classroom. Universal Journal of Educational Research, 7(4A), 35 - 42. DOI: 10.13189/ujer.2019.071406, 2019 